DOI: https://doi.org/10.47405/aswj.v5i3.151

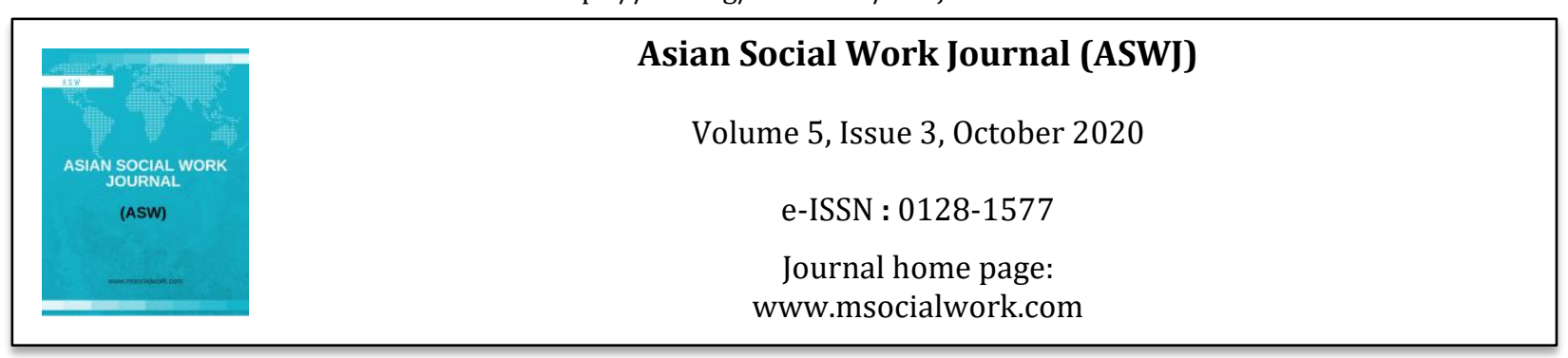

\title{
Introduction of Institution and Program of the International Non-Government Organization on Child Protection Efforts in the Jabodetabek Area
}

\author{
RR Endah Sulistyaningsih ${ }^{1}$, Alfrojems ${ }^{2}$ \\ 1Planning Bureau of the Secretariat General, Ministry of Social Affairs of the Republic of Indonesia \\ 2Faculty of Social and Political Sciences, University of Indonesia \\ Correspondence: Alfrojems (alfro.jems@gmail.com)
}

\begin{abstract}
The aim of this research is to describe the introduction of International Non-Government Organization (INGO) institutions and programs received by beneficiaries. To meet these objectives, this research method uses quantitative descriptive type. The sampling technique used is stratified proportional sampling. The number of respondents in this study amounted to 325 respondents. The results revealed that this study indicate that most people have an introduction to the program in the intermediate category.
\end{abstract}

Keywords: child protection, international non-government organization, welfare

\section{Introduction}

The existence of the International Non-Government Organization (INGO) in Indonesia is undeniably contributing to solving child problems in Indonesia. International organizations that provide services to the community in the field of children include Wahana Visi Indonesia (WVI) and Childfund. Indonesia is one of the countries that has ratified children's rights which has resulted in a derivative of the policy of Law Number 35 of 2014 concerning Amendments to Law Number 23 of 2002 concerning Child Protection. This policy provides strong arguments for the importance of program implementation in ensuring the implementation of these regulations which of course aims to ensure the welfare of Indonesian children. The presence of children in the family requires protection and assistance with the aim of obtaining a decent life (Mayasari, 2018). In order to maximize this goal, opportunities have also been opened for International Non-Government Organizations to be able to implement programs in an effort to protect children as well as to achieve the welfare conditions of Indonesian children. more importantly, it is important to understand that efforts to realize protection for children require concrete and holistic steps (Roche, 2017). While children protection also needs security device and community participation (Indriati, et al, 2017).

Children are an age group that is under the age of 18 years (Hurlock, 1980). It is further that the age group of children if they are grouped again, they will be divided into seven more groups, namely prenatal period, new-born period, infancy, early childhood, late childhood, puberty, and adolescence. A child is someone who is not yet 18 (eighteen) years old, including children who are still in the womb (Law Number 35 of 2014 article 1 paragraph 1). Based on this statement, information is obtained related to what is meant by children. The child population, which reaches $24.8 \%$ of the total population of Indonesia, illustrates the importance of efforts to ensure children's growth and development and to ensure that children are protected from efforts that can hamper children's growth and development. The 
efforts made need to be understood by all parties and their implementation requires attention as well as good supervision from the government. The population of children owned by Indonesia provides an illustration of the importance of ensuring a safe and comfortable environment for the development of Indonesian children, so that they can become a generation ready to continue national development. Therefore, child protection is all activities to guarantee and protect children and their rights so that they can live, grow, develop and participate optimally in accordance with human dignity and protection from violence and discrimination (Law Number 35 years). 2014 article 1 paragraph 2).

In several studies such as according to Fitriani (2016) which states that child protection is related to strength by five pillars such as parents, family, community, government, in this case the central and regional governments. Through this research, INGO can carry out its programs in collaboration with parents, family, community, government, in this case the central and regional governments, which of course comply with the provisions of the applicable regulations. As for the results of this study, the purpose of this study is to find an overview of the introduction of INGO institutions and programs received by beneficiaries or program services. The International Non-Government Organization is one of the important actors in the distribution of foreign aid and philanthropy, furthermore the role of INGO has increased after the cold war in 1991 (Rasyidah, 2014). From the results of some of these studies, it is clear that there is no or still a few studies that discuss how INGO provides introduction to institutions and programs to beneficiaries. Therefore, this research is intended to describe the introduction of INGO institutions and programs received by the beneficiaries.

\section{Methodology}

This research uses a quantitative approach through a descriptive survey. According to Neuman (2014) quantitative is more concerned about issues of design, measurement, and sampling because their deductive approach emphasizes detailed planning prior to data collection and analysis. Whereas according to Burn, a descriptive survey aims to estimate as much as possible the nature of existing conditions, or the attributes of a population; for example, its demographic composition, its attitude to abortion, its religious beliefs, voting intentions, its childrearing practice (Burn, 2000 in Silalahi, 2015). The data collection techniques used in this study were questionnaire instruments, and literature review documentation studies. The sampling technique in this study is cluster probability sampling. According to Singh (2007) in Silalahi (2015), cluster sampling signifies that instead of selecting individual units from the population, entire groups or clusters are selected at random. In cluster sampling, first we divide the population into clusters, then we randomly select some clusters from all clusters formed and measure all units within the sampled clusters.

The number of samples in this study was 325 people, as determined by the Slovin formula with an error margin of 5 percent. As for the characteristics of the respondents in this study, respondents are parents or guardians who participate in programs organized by international non-governmental organizations, namely ChildFund and WVI. The survey instrument used in this study is a questionnaire with closed questions and a Likert scale as the rating scale. This study uses nominal data for the value of each question and has an interval value for the whole question. The validity of the research instrument was tested through the application of the 25th SPSS series and all questions were valid with a reliability number of ,896 on the Cronbach alpha scale. Related to the accumulation of accumulative data, in this study, the researcher made a classification assessment using three groups with the initial stage of determining the class interval and formula as follows.

$$
\begin{aligned}
& \mathbf{K}=\frac{\mathbf{R}}{\mathbf{i}} \\
& \text { Explanation: } \\
& \mathrm{K} \quad \text { : Number of class intervals } \\
& \mathrm{R} \quad \text { : Range } \\
& \mathrm{I} \quad \text { : Class interval }
\end{aligned}
$$


DOI: https://doi.org/10.47405/aswj.v5i3.151

In addition to completing this research, the interval data is analyzed by calculating the average score that has been set and then grouped on a continuum with a range of intervals determined according to the number of groups (Sugiyono, 2012). In this study, to determine the total value is the number of questions (16) $\mathrm{x}$ the number of respondents (325) x the highest number of values (5).

As for supporting the achievement of this research, what is done by researchers is to make instruments that are in accordance with the objectives of this study. This research instrument uses a Likert scale with five choices where each choice has a different value. The range of values on the answer choices in this instrument is from the smallest 1 to the highest value is 5. For more details, see the table below:

Table 1: Questions of Instrument

\begin{tabular}{|c|c|c|c|c|c|c|}
\hline \multirow{2}{*}{ NO. } & \multirow{2}{*}{ QUESTIONS } & \multicolumn{5}{|c|}{ OPTIONS OF ANSWERS } \\
\hline & & 1 & 2 & 3 & 4 & 5 \\
\hline 1. & $\begin{array}{l}\text { Do you know the staff of } \\
\text { the organization [name of } \\
\text { organization]? If yes, how } \\
\text { many staff do you know }\end{array}$ & $\begin{array}{l}\text { Do not } \\
\text { know } \\
\text { any }\end{array}$ & $\begin{array}{c}\text { Few (1-2 } \\
\text { people) }\end{array}$ & $\begin{array}{c}\text { Some (3-5 } \\
\text { people) }\end{array}$ & $\begin{array}{l}\text { Many (more } \\
\text { than } 5 \\
\text { people) }\end{array}$ & All \\
\hline
\end{tabular}
and state their names.

2. Do you know who to communicate with if there are obstacles during the program? (barriers in the form of difficulty understanding or accessing additional information)

3. Are you satisfied with the facilities provided by the organization?

4. How often do you communicate with the organization?

5. Are you satisfied with the services provided by the organization?

6. Have you had any disputes with organizational staff?

7. Do you always have problems with the facilities or equipment available at the Society?

$\begin{array}{ccccc}\text { Not } & \text { Less } & \text { Sufficiently } & \text { Knowing } & \text { Very } \\ \text { Knowin } & \text { Knowing } & \text { Knowing } & & \text { Knowing } \\ \mathrm{g} & & & \end{array}$

$\begin{array}{ccccc}\text { Not } & \text { Less } & \text { Quite } & \text { Satisfied } & \text { Very } \\ \text { Satisfie } & \text { Satisfied } & \text { Satisfied } & & \text { Satisfied } \\ \text { d } & & & & \end{array}$

Never Rarely Sometimes Often Always

$\begin{array}{ccccc}\text { Not } & \text { Less } & \text { Quite } & \text { Satisfied } & \text { Very } \\ \begin{array}{c}\text { Satisfie } \\ \text { d }\end{array} & \text { Satisfied } & \text { Satisfied } & & \text { Satisfied }\end{array}$

Never Rarely Sometimes Often Always

Always Often Sometimes Rarely Never 
DOI: https://doi.org/10.47405/aswj.v5i3.151

\begin{tabular}{|c|c|c|c|c|c|c|}
\hline 8. & $\begin{array}{l}\text { Are you involved in any } \\
\text { program planning? }\end{array}$ & Never & Rarely & Sometimes & Often & Always \\
\hline 9. & $\begin{array}{l}\text { Do you know what } \\
\text { programs this organization } \\
\text { carries out? }\end{array}$ & $\begin{array}{l}\text { Not } \\
\text { Knowin } \\
\text { g }\end{array}$ & $\begin{array}{c}\text { Less } \\
\text { Knowing }\end{array}$ & $\begin{array}{l}\text { Sufficiently } \\
\text { Knowing }\end{array}$ & Knowing & $\begin{array}{c}\text { Very } \\
\text { Knowing }\end{array}$ \\
\hline 10. & $\begin{array}{l}\text { Do you know the purpose } \\
\text { of the activities you have } \\
\text { participated in or done? }\end{array}$ & $\begin{array}{l}\text { Not } \\
\text { Knowin } \\
\text { g }\end{array}$ & $\begin{array}{c}\text { Less } \\
\text { Knowing }\end{array}$ & $\begin{array}{l}\text { Sufficiently } \\
\text { Knowing }\end{array}$ & Knowing & $\begin{array}{c}\text { Very } \\
\text { Knowing }\end{array}$ \\
\hline 11. & $\begin{array}{l}\text { Are you comfortable with } \\
\text { the programs provided by } \\
\text { the organization? }\end{array}$ & $\begin{array}{l}\text { Not } \\
\text { Comfort } \\
\text { able }\end{array}$ & $\begin{array}{c}\text { Less } \\
\text { Comfortable }\end{array}$ & $\begin{array}{l}\text { Quite } \\
\text { Comfortabl } \\
\text { e }\end{array}$ & Comfortable & $\begin{array}{c}\text { Very } \\
\text { Comfortabl } \\
\mathrm{e}\end{array}$ \\
\hline 12. & $\begin{array}{l}\text { Do you often participate in } \\
\text { activities organized by this } \\
\text { organization? }\end{array}$ & Never & Rarely & Sometimes & Often & Always \\
\hline 13. & $\begin{array}{l}\text { Do you know the function } \\
\text { of each type of service or } \\
\text { program provided by the } \\
\text { organization? }\end{array}$ & $\begin{array}{l}\text { Not } \\
\text { Knowin } \\
\text { g }\end{array}$ & $\begin{array}{c}\text { Less } \\
\text { Knowing }\end{array}$ & $\begin{array}{l}\text { Sufficiently } \\
\text { Knowing }\end{array}$ & Knowing & $\begin{array}{c}\text { Very } \\
\text { Knowing }\end{array}$ \\
\hline 14. & $\begin{array}{l}\text { Have you always benefited } \\
\text { from the implementation of } \\
\text { programs carried out by the } \\
\text { organization? }\end{array}$ & Never & Rarely & Sometimes & Often & Always \\
\hline 15. & $\begin{array}{l}\text { Have you ever experienced } \\
\text { problems / obstacles with } \\
\text { the stages of service or } \\
\text { programs being } \\
\text { implemented? }\end{array}$ & Never & Rarely & Sometimes & Often & Always \\
\hline 16. & $\begin{array}{l}\text { Are the results of program } \\
\text { implementation consistent } \\
\text { with your desired } \\
\text { expectations? }\end{array}$ & Never & Rarely & Sometimes & Often & Always \\
\hline
\end{tabular}

Source: processed by researchers (2020) 


\section{Findings and Discussion}

Research carried out after going through the data collection process and then conducting data management, the results obtained from the results of this study with the aim of seeing a picture of knowing the description of the introduction of INGO institutions and programs received by the recipient, the following results are obtained:

Table 2: Knowing the Staff of Organization

\begin{tabular}{llrrr}
\hline & Frequency & Percent & Valid Percent & $\begin{array}{c}\text { Cumulative } \\
\text { Percent }\end{array}$ \\
\hline Valid 1 (do not know any) & 24 & 7,3 & 7,4 & 7,4 \\
2 (Few) & 117 & 35,8 & 36,1 & 43,5 \\
3 (Some) & 77 & 23,5 & 23,8 & 67,3 \\
4 (Many) & 80 & 24,5 & 24,7 & 92,0 \\
5 (All) & 26 & 8,0 & 8,0 & 100,0 \\
Total & 325 & 100,00 & 100,0 & \\
\hline
\end{tabular}

The research result on the first question is about "Do you know the staff of the organization? If yes, how many staff do you know and state their names? It shows that the majority answered a little (2) with a percentage of $35.8 \%$, followed by many (4) with a percentage reaching $24 \%$ and some (3) with a percentage reaching $23.5 \%$. This result shows that the beneficiaries are mostly familiar with the staff of the organizations that provide them with services, although not entirely.

Table 3: Knowing Who the Right Person for Communicate on Program

\begin{tabular}{llrrrr}
\hline & Frequency & Percent & Valid Percent & \multicolumn{2}{c}{ Cumulative } \\
Percent
\end{tabular}

Based on the research results in the table 3rd above with the question of "Do you know who to communicate with if there are obstacles during the program?" shows the results where those who have the most majority choice are knowing (4) with a percentage reaching $59.6 \%$ which is then followed by knowing enough (3) with a percentage reaching $18.0 \%$ and then very knowing (5) with a percentage of $8.3 \%$. This result shows that the beneficiaries already know who they will communicate to if there are obstacles in the implementation of their programs.

Table 4: Satisfaction the Facilities of Organization

\begin{tabular}{|c|c|c|c|c|c|}
\hline & & Frequency & Percent & Valid Percent & $\begin{array}{c}\text { Cumulative } \\
\text { Percent }\end{array}$ \\
\hline \multirow{6}{*}{ Valid } & 1 (Not Satisfied) & 1 & ,3 & ,3 & 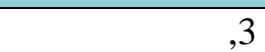 \\
\hline & 2 (Less Satisfied) & 4 & 1,2 & 1,2 & 1,5 \\
\hline & 3 (Quite Satisfied) & 113 & 34,6 & 34,8 & 36,3 \\
\hline & 4 (Satisfied) & 149 & 45,6 & 45,8 & 82,2 \\
\hline & 5 (Very Satisfied) & 58 & 17,7 & 17,8 & 100,0 \\
\hline & Total & 325 & 100,00 & 100,0 & \\
\hline
\end{tabular}

The results of this study are in particular in the table 4th with the question "Are you satisfied with the facilities provided by the organization?" It shows that the choice that has the most number or is the 
DOI: https://doi.org/10.47405/aswj.v5i3.151

majority chosen is satisfied (4) with a percentage reaching $45.6 \%$ which is then followed by quite satisfied (3) with a percentage reaching $34.6 \%$, after that the next highest is very satisfied (5) with a percentage reaching $17.7 \%$. Based on the results of this study, it is clear that the beneficiaries are satisfied with the existing facilities provided by the organization.

Table 5: Frequency for Communicate with Staff of Organization

\begin{tabular}{llrrrr}
\hline & Frequency & Percent & Valid Percent & $\begin{array}{c}\text { Cumulative } \\
\text { Percent }\end{array}$ \\
\hline Valid & 1 (Never) & 17 & 5,2 & 5,2 & 5,2 \\
2 (Rarely) & 52 & 15,9 & 16,0 & 21,2 \\
3 (Sometimes) & 85 & 26,0 & 26,2 & 47,4 \\
4 (Often) & 145 & 44,3 & 44,6 & 92,0 \\
5 (Always) & 26 & 8,0 & 8,0 & 100,0 \\
Total & 325 & 100,00 & 100,0 & \\
\hline
\end{tabular}

Based on the data shown in the table 5th above with the question "how often do you communicate with the organization?" shows that the most or the majority of choices are frequent choices (4) which reach a percentage of $44.6 \%$, then sometimes (3) reach a percentage of reaching $26.2 \%$, and the last three are rare (2) reaching a percentage of $16.0 \%$. So, it can be said that the majority of beneficiaries have communicated with the program implementing agencies.

Table 6: Satisfied the Services of Organization During Program

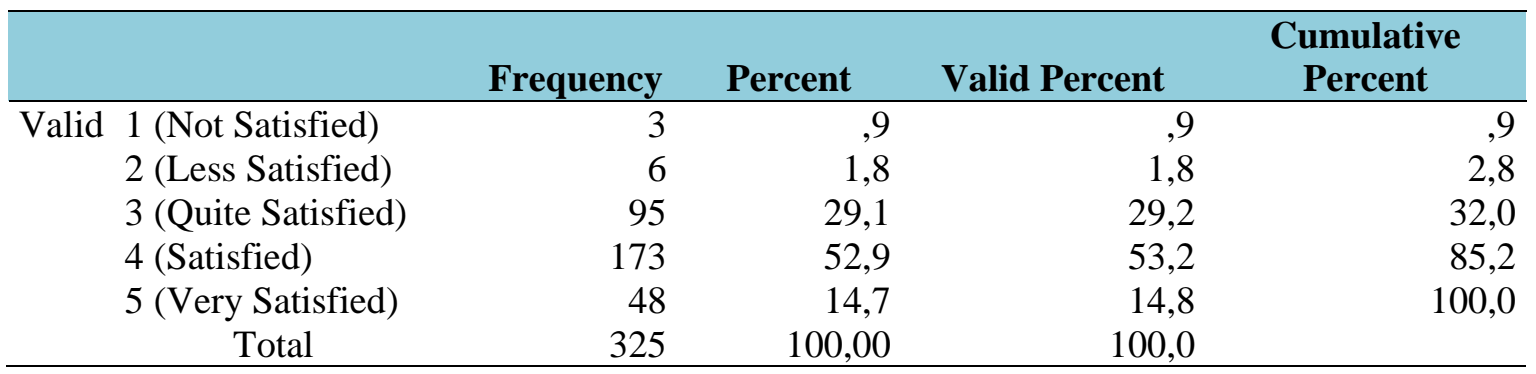

Based on the table above, information is obtained that, for the question "Are you satisfied with the services provided by the organization?". The majority of respondents answered 4 (satisfied) with a value of $52.9 \%$, then answered 3 (quite satisfied) with a value of $29.1 \%$ while the third highest was the majority of respondents answered 5 (very satisfied) with a value of $14.7 \%$. Based on these data, it can be concluded that the services provided by INGO to beneficiaries are quite good.

Table 7: Conflict with Staff of the Organization

\begin{tabular}{|c|c|c|c|c|c|}
\hline & & Frequency & Percent & Valid Percent & $\begin{array}{c}\text { Cumulative } \\
\text { Percent }\end{array}$ \\
\hline Valid & 1 (Never) & 47 & 14,4 & 14,5 & 14,5 \\
\hline & 2 (Rarely) & 3 & 9 & 9 & 15,4 \\
\hline & 3 (Sometimes) & 6 & 1,8 & 1,8 & 17,2 \\
\hline & 4 (Often) & 8 & 2,4 & 2,5 & 19,7 \\
\hline & 5 (Always) & 261 & 79,8 & 80,3 & 100,0 \\
\hline & Total & 325 & 100,00 & 100,0 & \\
\hline
\end{tabular}

In the table above for the aspect of the question about "Have you ever had conflicts with organizational staff?". for this question, there are results that are quite contradictory to the satisfaction with service questions in the previous table. This is because $79.8 \%$ of respondents answered 5 (always) had a dispute with the staff of the organization that provided services to them, then $14.4 \%$ answered 1 (never), and the third majority was 4 (often) with a value of $2.4 \%$. This shows that disputes over 
DOI: https://doi.org/10.47405/aswj.v5i3.151

program implementation are not something new. But the most important thing is about how to resolve these disputes.

Table 8: Problem with Facilities or Equipment in the Society

\begin{tabular}{llrrrr} 
& & & & Cumulative \\
& Frequency & Percent & Valid Percent & Percent \\
\hline Valid & 1 (Always) & 84 & 25,7 & 25,8 & 25,8 \\
2 (Often) & 4 & 1,2 & 1,2 & 27,1 \\
3 (Sometimes) & 3 &, 9 &, 9 & 28,0 \\
4 (Rarely) & 16 & 4,9 & 4,9 & 32,9 \\
5 (Never) & 218 & 66,7 & 67,1 & 100,0 \\
Total & 325 & 100,00 & 100,0 & \\
\hline
\end{tabular}

The table above shows the results of the question about "do you always have problems with the facilities or equipment in the Society?" which shows that the majority of beneficiaries choose to answer 5 or have never had problems with the facilities and infrastructure owned by the organization in carrying out services with a figure of $66.7 \%$. Furthermore, the majority of respondents answered 1 (always) with a rate of $25.7 \%$, and the last one was 4 (rarely). These figures or data indicate that the existing facilities and infrastructure are good but still cannot answer all the needs required by respondents.

Table 9: Involved in Any Program Planning

\begin{tabular}{llrrrr}
\hline & & & & Cumulative \\
& & Frequency & Percent & Valid Percent & Percent \\
\hline Valid & 1 (Never) & 49 & 15,0 & 15,1 & 15,1 \\
2 (Rarely) & 38 & 11,6 & 11,7 & 26,8 \\
3 (Sometimes) & 96 & 29,4 & 29,5 & 56,3 \\
4 (Often) & 80 & 24,5 & 24,6 & 80,9 \\
5 (Always) & 62 & 19,0 & 19,1 & 100,0 \\
Total & 325 & 100,00 & 100,0 & \\
\hline
\end{tabular}

The next table shows the results for the question "were you involved in any program planning?". Based on the data above, it shows that the majority of respondents choose 3 (sometimes) with the number 29.4 , then the majority is choice number 4 (often) with the number $24.5 \%$ and the third answer is 5 (always) with the number $19.0 \%$. Based on the data above, information can be obtained that in general the majority of respondents or beneficiaries feel involved in every service process received by them.

Table 10: Knowing about What Organization Carries Out in Program

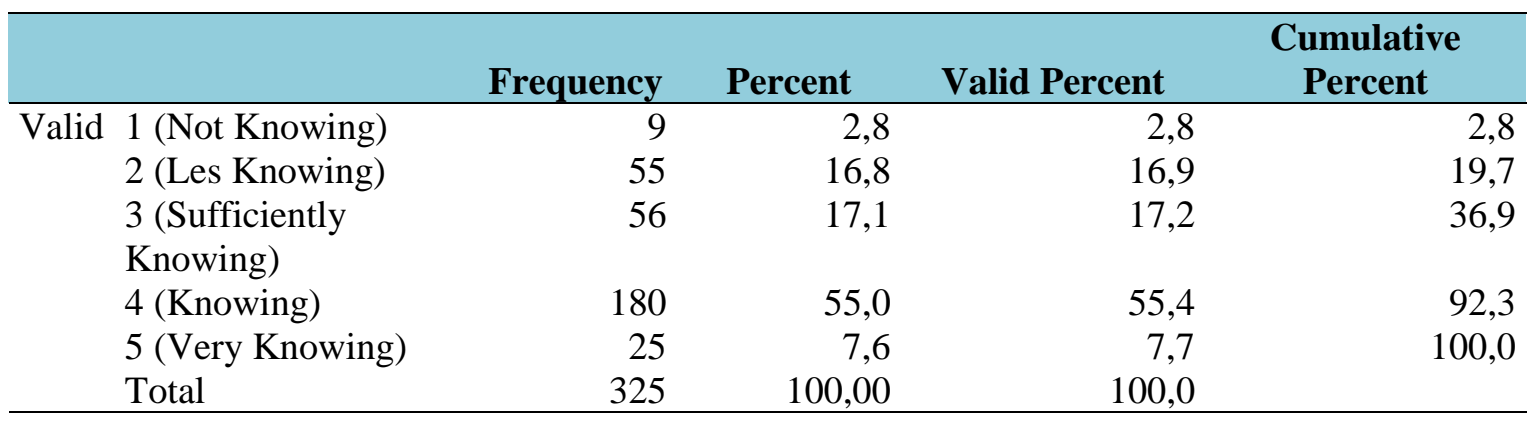

The table above shows the data related to the question of "do you know what programs this organization carries out?", Where the results show that the majority of respondents chose number 4 (knowing) with a percentage value of $55.4 \%$, followed by number 3 (knowing enough) with a percentage of $17.1 \%$ and the third majority chosen was number 2 (not knowing enough) with a percentage value reaching $16.8 \%$. Through the results or data obtained above, a description or 
DOI: https://doi.org/10.47405/aswj.v5i3.151

information is obtained that in fact almost all participants or respondents know about the programs being held in the organization.

Table 11: Knowing Purpose of the Activities

\begin{tabular}{|c|c|c|c|c|c|}
\hline & & Frequency & Percent & Valid Percent & $\begin{array}{c}\text { Cumulative } \\
\text { Percent }\end{array}$ \\
\hline \multirow[t]{7}{*}{ Valid } & 1 (Not Knowing) & 3 & ,9 & ,9 & 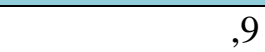 \\
\hline & 2 (Les Knowing) & 23 & 7,0 & 7,1 & 8,0 \\
\hline & 3 (Sufficiently & 216 & 66,1 & 66,5 & 74,5 \\
\hline & Knowing) & & & & \\
\hline & 4 (Knowing) & 50 & 15,3 & 15,4 & 89,8 \\
\hline & 5 (Very Knowing) & 33 & 10,1 & 10,2 & 100,0 \\
\hline & Total & 325 & 100,00 & 100,0 & \\
\hline
\end{tabular}

For the next question is "do you know the purpose of the activities that you have ever participated in or lived?. Based on the data in the table above, it is found that the majority of respondents answered or chose number 3 (knowing enough) with a percentage value reaching $66.5 \%$, then the majority choice from number 4 (knowing) with a percentage value reaching $15.4 \%$ and The third majority chosen by the respondents was number 5 (very knowledgeable) with a value reaching $10.1 \%$. Based on these data, it is obtained an illustration that most of the respondents know the purpose of the activities the respondent has participated in or undertaken.

Table 12: Comfortable with Program of the Organization

\begin{tabular}{lrrrr} 
& & & & \multicolumn{2}{c}{$\begin{array}{c}\text { Cumulative } \\
\text { Percent }\end{array}$} \\
\hline Valid 1 (Not Comfortable) & Frequency & Percent & Valid Percent & .3 \\
2 (Less Comfortable) & 1 & .3 & .3 & 1.2 \\
3 (Quite Comfortable) & 3 & .9 & .9 & 65.6 \\
4 (Comfortable) & 208 & 63.6 & 64,4 & 84.2 \\
5 (Very Comfortable) & 61 & 18.3 & 18.6 & 100.0 \\
Total & 52 & 15.6 & 15.8 & \\
\hline
\end{tabular}

The next table discusses the results of the respondents' choices regarding the question "are you comfortable with the programs provided by the organization?". Based on the data in the table above, it is obtained an illustration that the majority of respondents who were asked chose to answer option number 3 (quite comfortable) with a percentage value reaching 64.3\%. Furthermore, the second majority chosen was number 4 (comfortable) with a percentage value reaching $18.3 \%$ and the third majority choice was number 5 (very comfortable) with a percentage value reaching $15.6 \%$. Through the data above, it can be obtained a general picture that the respondents as beneficiaries of the program mostly feel quite comfortable with the program they are running.

Table 13: Participating in Activities of the Organization

\begin{tabular}{llrrrr}
\hline & & Frequency & Percent & Valid Percent & Cumulative \\
Percent
\end{tabular}

The next table is the answer to the question about "do you often participate in activities organized by this organization?. Based on the data in the table above, it is obtained an illustration that the majority 
DOI: https://doi.org/10.47405/aswj.v5i3.151

of respondents who were asked chose to answer choice number 4 (often) with a percentage value reaching $47.4 \%$. Furthermore, the second majority chosen was number 3 (sometimes) with a percentage value reaching $23.9 \%$ and the third majority choice was number 5 (always) with a percentage value reaching $14.7 \%$. Based on the data, it is found that most of the respondents often participate in activities organized by the organizations that organize the program.

Table 14: Knowing Function of the Program

\begin{tabular}{llrrrr}
\hline & Frequency & \multicolumn{1}{c}{ Percent } & Valid Percent & $\begin{array}{c}\text { Cumulative } \\
\text { Percent }\end{array}$ \\
\hline Valid & 1 (Not Knowing) & 7 & 2,1 & 2,2 & 2,2 \\
& 2 (Les Knowing) & 35 & 10,7 & 10,8 & 12,9 \\
3 (Sufficiently & 204 & 62,4 & 62,8 & 75,7 \\
Knowing) & & & & \\
4 (Knowing) & 56 & 17,1 & 17,2 & 92,9 \\
5 (Very Knowing) & 23 & 7,0 & 7,1 & 100,0 \\
Total & 325 & 100.00 & 100,0 & \\
\hline
\end{tabular}

The next table is a table that discusses the results of respondents' choices for the question "do you know the function of each type of service or program provided by the organization?. Based on the data in the table above, an illustration shows that the majority of respondents who were asked chose to answer option number 3 (knowing) with a percentage value reaching 62.8\%. Furthermore, the second majority chosen was number 4 (knowing enough) with a percentage value reaching $17.2 \%$ and the third majority choice was number 2 (not knowing enough) with a percentage value reaching $10.7 \%$. Based on the data generated as in the table, information is obtained that most respondents or program beneficiaries already know the function of each type of service or program they receive.

Table 15: Obtain Benefited of The Program

\begin{tabular}{llrrrr}
\hline & & Frequency & Percent & Valid Percent & \multicolumn{2}{c}{ Cumulative } \\
Percent
\end{tabular}

The next table discusses the results for the question "have you always benefited from the implementation of programs carried out by the organization?". Based on the data in the table above, an illustration shows that the majority of respondents who were asked chose to answer choice number 5 (always) with a percentage value reaching $44.0 \%$. Furthermore, the second majority chosen was number 4 (often) with a percentage value reaching $29.1 \%$ and the third majority choice was number 3 (sometimes) with a percentage value reaching $18.7 \%$. Based on these results, information is obtained that in fact most of the respondents have benefited from the implementation of the program that is being undertaken by them through the organization.

Table 16: Have Any Problem Experienced

\begin{tabular}{llrrr} 
& & & & Cumulative \\
& Frequency & \multicolumn{1}{c}{ Percent } & Valid Percent & Percent \\
\hline Valid 1 (Never) & 42 & 12,8 & 12,9 & 12,9 \\
2 (Rarely) & 8 & 2,4 & 2,5 & 15,4 \\
3 (Sometimes) & 70 & 21,4 & 21,5 & 36,9 \\
4 (Often) & 48 & 14,7 & 14,8 & 51,7 \\
5 (Always) & 157 & 48,0 & 48,3 & 100,0
\end{tabular}


DOI: https://doi.org/10.47405/aswj.v5i3.151

Total

325

100.00

100,0

The next table discusses the results of the respondent's choice with the question "have you ever experienced problems / obstacles with the stages of service or programs being implemented?". Based on the data in the table above, it is obtained an illustration that the majority of respondents who were asked chose to answer choice number 5 (always) with a percentage value reaching $48.0 \%$. Furthermore, the second majority chosen was number 4 (often) with a percentage value reaching $14.7 \%$ and the third majority choice was number 1 (never) with a percentage value reaching $12.8 \%$. From the results of this data, information is obtained that in fact most of the respondents in carrying out the stages of service have experienced or faced problems/obstacles.

Table 17: Suitability between Reality with Expectation

\begin{tabular}{llrrrr}
\hline & Frequency & Percent & Valid Percent & $\begin{array}{c}\text { Cumulative } \\
\text { Percent }\end{array}$ \\
\hline Valid & 1 (Never) & 6 & 1,8 & 1,8 & 1,8 \\
& 2 (Rarely) & 9 & 2,8 & 2,8 & 4,6 \\
& 3 (Sometimes) & 127 & 38,8 & 39,1 & 43,7 \\
& 4 (Often) & 91 & 27,8 & 28,0 & 71,7 \\
& 5 (Always) & 92 & 28,1 & 28,3 & 100,0 \\
& Total & 325 & 100.00 & 100,0 & \\
\hline
\end{tabular}

The next table as the final table to describe the results of this study tries to elaborate on the results of the respondents' choices related to the question "are the results of program implementation always in accordance with the expectations you want? Based on the data in the table above, an illustration shows that the majority of respondents who were asked chose to answer option number 3 (sometimes) with a percentage value reaching $38.8 \%$. Furthermore, the second majority chosen was number 5 (always) with a percentage value reaching $28.3 \%$ and the third majority choice was number 4 (often) with a percentage value reaching $27.8 \%$. Based on the data above, information is obtained that respondents have a tendency that the beneficiaries feel that the programs they have implemented or are currently implementing are able to meet their expectations as they wanted since they joined the INGO program.

\section{Conclusion}

In general, based on the data obtained from the answers given by respondents to the instruments distributed to respondents, it shows that the introduction of institutions and programs carried out by international non-government organizations (INGO) is quite good. However, it needs a fairly concrete effort from INGO to pay attention to the closeness between employees and beneficiaries. This is an important point because service which is a process and must be passed in a long enough time requires a high enough trust factor between the beneficiaries and the implementer, in which case INGO is represented by the employee. In addition to that, INGO also needs to pay attention to the program to increase the understanding of the beneficiaries of the benefits of the program to the beneficiaries, so that it is hoped that the beneficiaries can be motivated again in carrying out these stages and are eager to always be present in every activity carried out.

In addition, it is also necessary to take concrete steps from the government, in this case both the central and local governments in giving awards to the implementation of INGO in Indonesia, because so far what has been done by the government is only to provide oversight of program implementation but does not consider the complexity and benefits of the program in contributing. to create welfare for the community, especially the child age group. Through this method, it is also convinced to provide benefits in the form of high motivation from each INGO in providing quality services while creating a healthy competitive situation or atmosphere. 
DOI: https://doi.org/10.47405/aswj.v5i3.151

\section{Acknowledgment}

This research is will not be successfully implemented without any support and well commitment of the all member's team and also another institution particularly at this moment we want to acknowledge to Sub Deputy Foreign Cooperation of Planning Bureau of the Secretariat General Ministry of Social Affair of The Republic Indonesia and Australia Award Indonesia and also we want to thankful for our respondence and the both of international non-government organization which is Wahana Visi Indonesia (WVI) and Childfund Indonesia that pleased our team to involve with their program to collect the data during the research.

\section{References}

Fitriani Rini. (2016). Perananan Penyelenggara Perlindungan Anak dalam Melindungi dan Memenuhi Hak-Hak Anak. Jurnal Hukum Samudera Keadilan, 11(2).

Hurlock, E. B. (1980). Psikologi Perkembangan. Jakarta: Penerbit Erlangga.

Indonesia Government. (2014). Undang-Undang Nomor 35 tahun 2014 tentang Perubahan Atas Undang-Undang Nomor 23 tahun 2002 tentang Perlindungan Anak. Jakarta: Indonesia Government.

Indriati Noer Yuwanto, Wahyuningsih, Krishnoe Kartika Sanyoto and Suyadi. (2017). Perlindungan dan Pemenuhan Hak Anak. Jurnal UGM Mimbar Hukum, 29, 03. https://jurnal.ugm.ac.id/jmh/article/view/24315.

Mayasari Dian Ety. (2018). Perlindungan Hak Anak Kategori Juvenile Delinquency Children's Right Protection in The Juvenile Delinquency Category. Kanun Jurnal Ilmu Hukum, 20(3). https://doi.org/10.24815/kanun.v20i3.11837.

Nazir, Mohammad. (2011). Metode Penelitian. Bogor: Ghalia Indonesia

Neuman, W. L. (2014). Social Research Methods: Qualitative and Quantitative Approaches. New York: Pearson

Rasyidah Resa. (2014). INGO Sebagai Agent of Aid: Peran dan Kontribusi Oxfam International dalam Penyaluran Bantuan untuk Pengentasan Kemiskinan. Global \& Policy, 2(1), Januari-Juni 2014. http://eprints.upnjatim.ac.id/6469/1/12_95-103_Resa_Rasyidah_IINGO_sebagai_Agent_of_Aid.pdf. Accessed on September 2020.

Roche, S. (2017). Child Protection and Maltreatment in the Philippines: A Systematic Review of the Literature. Asia \& the Pacific Policy Studies, 4(1). Wiley Online Library. https://doi.org/10.1002/app5.167.

Silalahi Ulber. (2015). Metode Penelitian Sosial Kuantitatif. Bandung: Refika Aditama.

Sugiyono. (2012). Metode Penelitian Kombinasi. Bandung: Alfabeta. 